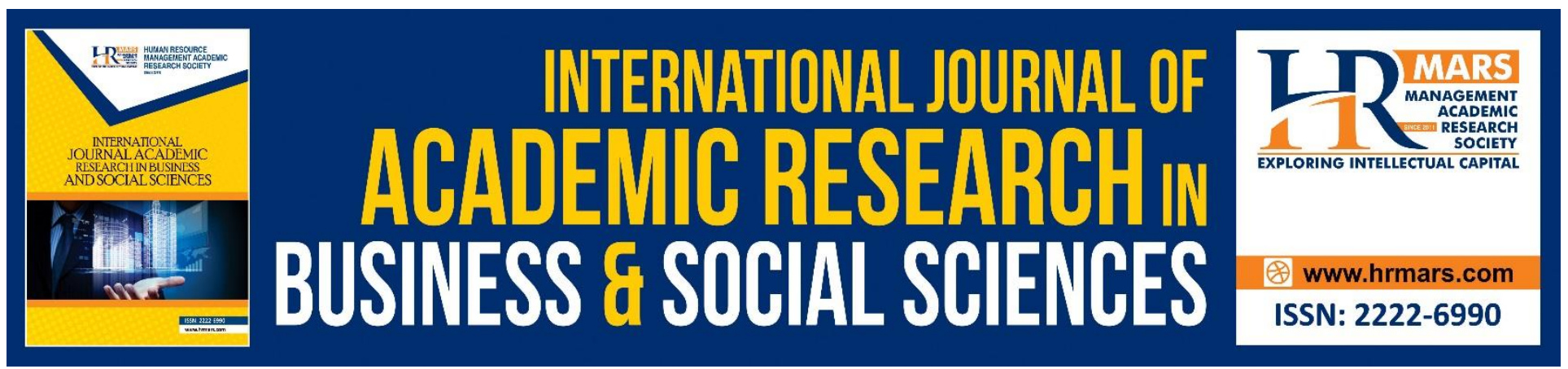

\title{
Code-Switching English-French in the Novel Petite Anglaise
}

\section{Amirah Syazwani Roslan \& Omrah Hassan @ Hussin}

To Link this Article: http://dx.doi.org/10.6007/IJARBSS/v10-i6/7335

DOI:10.6007/IJARBSS/v10-i6/7335

Received: 13 April 2020, Revised: 17 May 2020, Accepted: 07 June 2020

Published Online: 29 June 2020

In-Text Citation: (Amirah Roslan, 2020)

To Cite this Article: Amirah Syazwani binti Roslan \& Omrah Hassan @ Hussin (2020). Code-Switching EnglishFrench in the Novel Petite Anglaise. International Journal of Academic Research in Business and Social Sciences, 10(6), 595-607.

Copyright: (C) 2020 The Author(s)

Published by Human Resource Management Academic Research Society (www.hrmars.com)

This article is published under the Creative Commons Attribution (CC BY 4.0) license. Anyone may reproduce, distribute, translate and create derivative works of this article (for both commercial and non-commercial purposes), subject to full attribution to the original publication and authors. The full terms of this license may be seen

at: http://creativecommons.org/licences/by/4.0/legalcode

\section{Vol. 10, No. 6, 2020, Pg. 595 - 607}

Full Terms \& Conditions of access and use can be found at http://hrmars.com/index.php/pages/detail/publication-ethics 


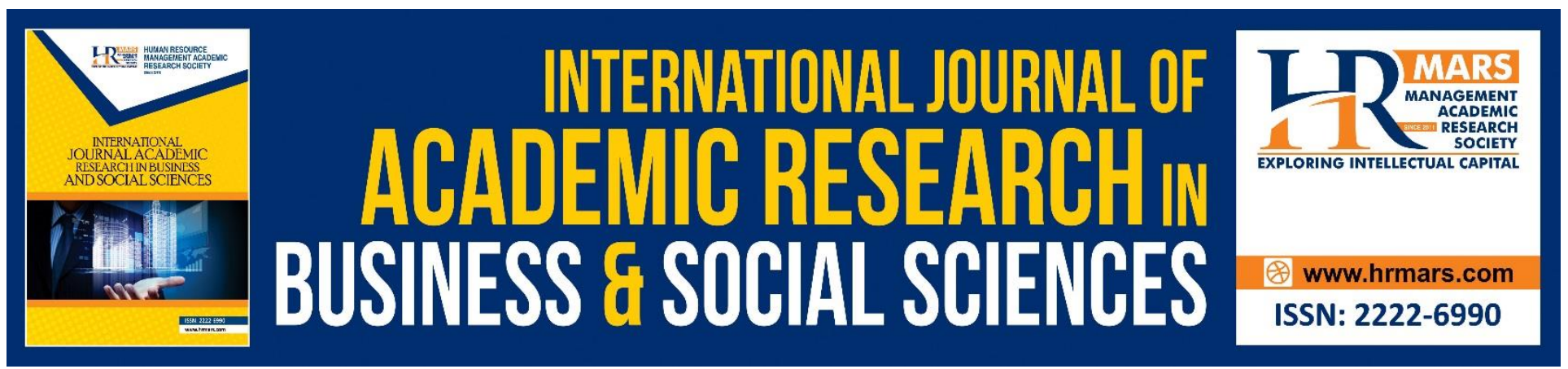

\title{
Code-Switching English-French in the Novel Petite Anglaise
}

\author{
Amirah Syazwani Roslan \& Omrah Hassan @ Hussin \\ Faculty of Modern Languages and Communication, Universiti Putra Malaysia, Malaysia.
}

\begin{abstract}
Code-switching has become a common language phenomenon that is widely used by each speaker who perceives and practices two or more languages in their daily lives. This common language phenomenon is looked up upon as the exchange of languages into other languages by speakers. This research aimed to discover the use of code-switching and the communicative functions of French as the second language used in an English novel entitled Petite Anglaise written by Catherine Sanderson. Moreover, this research involved analyzing the use of code-switching between English and French from all of the 34 chapters contained in the novel. The researchers have chosen the theoretical framework pioneered by Poplack (1980) to identify the three types of code-switching, namely tag code-switching, intrasentential code-switching and intersentential code-switching. Besides, this research also demonstrates the communicative functions of language, especially French, based on the theoretical framework presented by Halliday (1973). The findings show that each French word that was part of the code-switching phenomenon used by the author has the language communicative functions. Furthermore, based on the data analysis, each of the French words has played an important role to facilitate the author's messages through the dialogues of every character involved. The results of this research are also expected to benefit readers especially for those who are interested in French languages. This is because this research demonstrates the ability of codeswitching to assist in the acquisition of the foreign language even though through non-academic materials including the novel.
\end{abstract}

Keywords: Code-Switching, Communicative Function, Novel, English Language, French Language.

\section{Introduction}

The Code-switching phenomenon has been looked up as a major issue of analytic studies over the years including in the sociolinguistic field of foreign language acquisition studies. Previous researchers have shown their interest in the code-switching phenomenon to study, in particular the usage of language among society. Bilingualism is one of the main catalysts that has led to the culture of using code-switching among society in various levels of communication. This is in line with Wardaugh (2006) opinion that stated code-switching is used by people who are bilingual and multilingual. Next, this language phenomenon can be described as switching languages from one language to another either in written or spoken form. Due to the knowledge and desire to understand 
various languages, the culture of utilizing code-switching has become the choice of the society including those who work in creative industries such as the authors of the novels. They use it as a communicative tool to convey the entire messages contained in their writing. This research focuses on the code-switching that occurs throughout the Novel Petite Anglaise which is an English novel that uses French as the second language in this creative work. The novel was chosen as the study material as it has demonstrated the phenomenon of code-switching throughout the whole plot. All of the dialogues that contained the language phenomenon are subsequently classified according to different types of communicative functions. Moreover, communicative functions refer to the role of language use in communicating information between authors and readers (Kamus Besar Bahasa Indonesia, $\mathrm{KBBI}$ ). These aspects of language allow us to look at the cultural linkage of code-switching to enhance the readers' understanding of the French language involved through its communicative functions. As a result, this study is seen to be helpful to readers especially to those who are interested in learning the foreign language through another alternative, in particular a casual medium like the novel. Plus, in this case, the researchers describe and discuss code-switching based on the communicative functions which it serves through Catherine Sanderson's creative writing that has been chosen by the researchers.

\section{Literature Review}

Code-switching in foreign language acquisition and learning has become the topic of considerable study and debate among researchers over the years. There are much research has been conducted to study the language phenomenon in various communication platforms. Maros, Noorizan and Zakaria (2016) have conducted a study on the phenomenon of code-switching in the movie "Ola Bola" using Poplack's theory (1980). The film recorded the highest number of Malaysian box office collections in 2016. Not only that, the film is also based on Malaysian football that portrayed multiracial characters. Besides, this study also examines the factors that led to the occurrence of the language phenomenon based on the theory pioneered by David Crystal (1987). The researchers found that there are three factors give rise to code-switching which is, the inability of a speaker to introduce himself or someone in a language, the speaker wants to create an element of unity within a group and the speaker wants to convey his message to the listeners. Besides, qualitative methods were used to conduct this study and only scenes 1, 22, 29 and 55 were selected and analyzed as the study material. Overall, intersentential code-switching and intrasentential code-switching are seen frequently throughout the whole plot where the main purpose of using the language phenomenon is to create interaction between the characters involved.

Plus, Wiruma Tititan Adi (2018) conducted a study entitled "Code-Switching in Critical Eleven Novel". The study material was written by a famous Indonesian author named Ika Natassa. The novel is composed of two languages which are Indonesian and English. In addition, through this study, the researcher discusses the types of code-switching based on theory (Poplack, 1980) and the factors involved in code-switching based on the theory pioneered by Hoffman and Saville-Troike. Next, descriptive analysis methods have been established to achieve both objectives of this study. The results of this study found that intrasentential code-switching was most commonly used with 11 data, while intersentential code-switching and tag code-switching only consists of 9 data for each category. Moreover, eight factors influence the use of code-switching including discussing a topic, referencing 
a person, expressing empathy, connecting sentences, repetition, obtaining confirmation, softening or reinforcing a request or instruction and completing a lexical requirement.

Besides, the language communicative functions have been a highlight as the main aspect in the studies of the code-switching topic among the previous researchers. Abd. Wahab (2018) has been conducting a study entitled "Kajian Ciri dan Fungsi Komunikatif Bahasa Melayu Sabah Dalam Media Sosial". This study highlights the role of Bahasa Melayu Sabah as a communicative tool in daily interactions and presenting information in oral or written form. Halliday's Theory (1973) was the theoretical framework that carries out the research. The methodology of this study is a descriptive analysis in which she has collected and discussed relevant data on the use of Bahasa Melayu Sarawak from a homepage on Facebook called "Ni Kali Lah". Next, the data has been centered on the status updates and comment sections of the users which were published between May and July 2017 that were retrieved from the web site https://www.facebook.com/nikalilah/ini. The homepage has been established in 2010 and has approximately 206, 842 followers in July 2018. However, the homepage name has changed to Borneo Netizen by 2017. The study was dismantling that Bahasa Melayu Sabah that was used in the homepage was not only employed as the medium of interaction in local society but also entrust information to others that can be seen through the language communicative functions as described by Halliday (1973) namely instrumental functions, informative functions, personal functions, heuristic functions, regulatory functions, imaginative functions and interaction functions.

In general, various communication platforms have used code-switching as their communication tool. The studies conducted by Melissa, Noorizan, Zakaria (2016) and Adi (2018) have studied the phenomenon of code-switching as outlined by Poplack (1980). Meanwhile, a study conducted by Abd. Wahab (2018) has extensively discussed the communicative functions of language based on Halliday's (1973) theory. This research is seen to be helpful mainly for enhancing French language acquisition among readers through the communicative functions that appear from the code-switching English-French which have been used as a communicative tool in the Novel Petite Anglaise. Moreover, it has also demonstrated another learning alternative that can be used by those in the field of language acquisition and learning as it is proven that creative writing which is a casual reading material can also be useful to enhance the reader's interest and knowledge towards foreign language such as the French language.

\section{Research Objectives}

- Identify the types of code-switching that occur in the writing of the Novel Petite Anglaise.

- Discuss the communicative functions of the language derived from the usage of French in the English novel.

\section{Methodology}

This research was carried out through a qualitative approach, using corpus analysis methods or better known as qualitative methods. According to Moleong and Lexy J. (2007), qualitative approaches refer to research methods that produce visual representations of observable data. Through qualitative methods, all code-switching contained in the Novel Petite Anglaise has been identified under the three categorize of the language phenomenon. Simultaneously, the data are classified according to 
INTERNATIONAL JOURNAL OF ACADEMIC RESEARCH IN BUSINESS AND SOCIAL SCIENCES Vol. 10, No. 6, June, 2020, E-ISSN: 2222-6990 @ 2020 HRMARS

the respective language communicative functions. This was done to see how effective the code was to enhance the understanding of French as a second language that had been incorporated into the writing of the English novel. The researchers also translated some of these dialogues into English to compare the meaning in French which aimed at improving the understanding of the French words used in the study material.

\section{Research Instrument}

The instrument used in this study is the Novel Petite Anglaise that was written by a bilingual author named, Catherine Sanderson. This novel was published in 2008 and contains 34 chapters in total.

\section{Findings and Discussions}

This section will be discussing the findings towards the usage of code-switching and the communicative functions produced by the language phenomenon in an English Novel entitled Petite Anglaise. Next, descriptive analysis through numbers of data consisting of the French words and their meaning in English was used to discuss the findings. Firstly, the results of this study discovered that there were 139 data which consists of the dialogues containing the phenomenon of code-switching between English and French in the Novel Petite Anglaise. Not only that, after analyzing the language phenomenon contained in this creative work, the researchers also found that each of them has language communicative functions. Moreover, the results of this study have shown that this language phenomenon can improve readers' level of understanding towards a foreign language, in particular, French that has been used as a second language in Catherine Sanderson's creative work.

\section{Tag code-switching}

This type of code-switching refers to a language tag that is commonly used in the daily interaction of speakers in a language.

As a result of the content analysis process, tag code-switching is the least used type of codeswitching. This is because, the researchers have found that this type of code-switching is used only in chapter 5, on page 53 only. Table (1) is an example and description of this type of code-switching.

Table (1): Tag code-switching

\begin{tabular}{|c|c|l|}
\hline Bil & $\begin{array}{c}\text { Page } \\
\text { No. }\end{array}$ & \\
\hline 1. & 53 & Tadpole: 'Et...nine, TEN!' \\
\hline
\end{tabular}

According to Table (1), only one French word was used which is, "Et". The word is a commonly used conjunction in French daily interaction. Based on the Oxford Dictionary, the word means "and" when translated into English.

\section{Intrasentential code-switching}

Intrasentential code-switching refers to the exchange of codes that occur in the same phrase or sentence. According to Poplack (1980), intrasentential code-switching has a higher frequency of use than others. 
INTERNATIONAL JOURNAL OF ACADEMIC RESEARCH IN BUSINESS AND SOCIAL SCIENCES Vol. 10, No. 6, June, 2020, E-ISSN: 2222-6990 @ 2020 HRMARS

The opinion is completely in line with the findings of this study. This is because intrasentential code-switching has recorded the highest amount of 126 data in the Novel Petite Anglaise. Additionally, code-switching for this category has been used consistently in 27 chapters out of 34 chapters contained in the creative work. However, this section will describe in detail three examples of dialogues using intrasentential code-switching as shown in Table (2).

Table (2): Intrasentential code-switching

\begin{tabular}{|l|l|l|}
\hline Bil & $\begin{array}{c}\text { Page } \\
\text { No. }\end{array}$ & \\
\hline 1. & 49 & Catherine: "Hadn't he pretty much given me carte blanche to do as I pleased?" \\
\hline 2. & 126 & Catherine: "It was one of those rare coup de foundre moments, you know..." \\
\hline 3. & 179 & $\begin{array}{l}\text { Mr. Frog: "I don't much like going to the park on my own. People look at me } \\
\text { strangely. I'm sure they think I'm a papa du dimanche." }\end{array}$ \\
\hline
\end{tabular}

Table (2) above shows three samples of intrasentential code-switching consisting of French phrases. Firstly, according to the Cambridge Dictionary, the phrase "carte blanche" can be referred to as "complete freedom" in English. Meanwhile, the second phrase "coup de foundre", means "love at first sight" in English (Collins Dictionary). Last but not least, the phrase "papa du dimanche" can be referred to as "the father who takes care of his children by himself during the weekends" (Cambridge Dictionary).

\section{Intersentential code-switching}

Intersentential code-switching is the most complex type of code-switching. This is because it can only be performed by individuals with a high ability to understand and speak the languages involved in a context. Both aspects are important because intersentential code-switching occurs when there is a phenomenon of exchanging two different types of languages horizontally in two different sentences. Plus, according to Appel \& Muysken (1987:118), intersentential code-switching takes place after a sentence in the first language has been completed and starting the next sentence with another language.

The results display that this type of code-switching has only 12 data in the Novel Petite Anglaise. Next, only two characters which are Mr. Frog and Catherine appear to have used intersentential code-switching in the writing. This is because they both have a high ability to understand and speak English and French which is an important aspect that reflects the phenomenon of code-switching.

However, this section will only describe three examples of intersentential code-switching dialogues as shown below. 
INTERNATIONAL JOURNAL OF ACADEMIC RESEARCH IN BUSINESS AND SOCIAL SCIENCES Vol. 10, No. 6, June, 2020, E-ISSN: 2222-6990 @ 2020 HRMARS

Table (3) : Intersentential code-switching

\begin{tabular}{|c|c|c|}
\hline Bil & $\begin{array}{l}\text { Page } \\
\text { No. }\end{array}$ & Dialogue / Text \\
\hline 1. & 21 & $\begin{array}{l}\text { Mr. Frog: "Bonsoir les filles. 'I know you said I could bring a friend, but l'm pretty } \\
\text { new in Paris- I've just moved here to look for a job-and I don't know a lot of } \\
\text { people". }\end{array}$ \\
\hline 2. & 241 & Catherine: "J'ai fait une connerie! I've gone and left my keys at the office!" \\
\hline 3.. & 291 & $\begin{array}{l}\text { Mr. Frog: "Oh don't be too hard on yourself. They'll rally around. And you're } \\
\text { stronger than you think. Ca va aller, j'en suis sur". }\end{array}$ \\
\hline
\end{tabular}

Based on table (3), the researchers list three examples of dialogues that comprised intersentential code-switching. Firstly, the French dialogue that was emitted by Mr.Frog, "Bonsoir les filles" means "Good evening, both of you," in English (Cambridge Dictionary). Not only that, "J'ai fait une connerie!" that was express by Catherine's character means "I made a silly mistake" in English (https://www.linguee.com). Besides, the last dialogue of Mr. Frog, "Ca va aller, j'en suis sur" transmitted a meaning of "Everything will be okay" in English (Collins Dictionary).

In short, these three types of code-switching as mentioned by Poplack (1980) have their features. For tag code-switching, the researchers discovered that the structure is in simple forms of a word that can be easily utilized and spelled. Meanwhile, intrasentential code-switching that was used in the study material involved a special phrase in French that cannot be translated literally to English. Forbye, intersentential code-switching is the most complex type of code-switching since it requires high proficiency and understanding in both languages. Overall, these features indirectly make it easier for any individual, especially researchers to classify code-switching that occurs as per their category.

\section{French Communicative functions}

In total, there are seven language's communicative functions that have been proposed by Halliday (1973). However, this study will only focus on four communicative functions namely informative function, instrumental function, interaction function and personal function while heuristic function, regulatory function, imagination function will not be discussed. Besides, this section will only demonstrate French communicative functions that were utilized as the second communicative tool in the English novel. The following are the tables of translated dialogues containing French words that were divided specifically to these four language communicative functions:

\section{French Informative Function}

The language informative function refers to the use of language as a medium for communicating information. Besides, as stated by Halliday (1973), this type of language communicative function has referred to the employment of a language to exchange ideas, information, stories and news on various issues that occur in their daily lives. 
INTERNATIONAL JOURNAL OF ACADEMIC RESEARCH IN BUSINESS AND SOCIAL SCIENCES Vol. 10, No. 6, June, 2020, E-ISSN: 2222-6990 @ 2020 HRMARS

The results of the research elevate that this type of language communicative function contained in the Novel Petite Anglaise indicated the highest amount of 105 data out of the total 139 data. However, this section will only describe two dialogues that have underline the informative functions of French as shown below.

Table (4): French Informative Function

\begin{tabular}{|c|c|c|c|}
\hline Bil. & $\begin{array}{l}\text { Dialogue with } \\
\text { French words in the } \\
\text { novel }\end{array}$ & $\begin{array}{l}\text { Dialogue's translations of } \\
\text { French words into English }\end{array}$ & $\begin{array}{c}\text { Function } \\
\text { description }\end{array}$ \\
\hline 1. & $\begin{array}{l}\text { Catherine: "He'd brought } \\
\text { out my British side, } \\
\text { instead of croissants, I } \\
\text { now ate granary toast } \\
\text { and marmalade for } \\
\text { breakfast, washed down } \\
\text { with a bottomless cup of } \\
\text { tea, in place of my bowl } \\
\text { of café au lait" }\end{array}$ & $\begin{array}{l}\text { Catherine: "He'd brought out } \\
\text { my British side, instead of } \\
\text { croissants, I now ate granary } \\
\text { toast and marmalade for } \\
\text { breakfast, washed down with } \\
\text { a bottomless cup of tea, in } \\
\text { place of my bowl of milk } \\
\text { coffee". }\end{array}$ & $\begin{array}{l}\text { To allocate information on } \\
\text { French's desired beverage. }\end{array}$ \\
\hline 2. & $\begin{array}{l}\text { Catherine: "Seeing there } \\
\text { was no queue in the } \\
\text { baker's shop, I darted in } \\
\text { to fetch a pain aux } \\
\text { raisins". }\end{array}$ & $\begin{array}{l}\text { Catherine: "Seeing there was } \\
\text { no queue in the baker's shop, } \\
\text { I darted in to fetch a rainsin } \\
\text { bread". }\end{array}$ & $\begin{array}{l}\text { To provide information of } \\
\text { French's favoured food. }\end{array}$ \\
\hline
\end{tabular}

Based on the table (4), French is seen to furnish an informative function by providing insights and knowledge towards French society such as their prominent food and beverage.

\section{French Instrumental Function}

The instrumental function attribute to a type of communicative function that emphasizes the role of language as a means of communication in expressing a need or desire for a speaker or language user. For example, using a language to give directions, find requests, and provide instruction.

In total, 14 data have shown French instrumental function. Here are some examples of instrumental functions from the usage of French in the creative works: 
INTERNATIONAL JOURNAL OF ACADEMIC RESEARCH IN BUSINESS AND SOCIAL SCIENCES

Vol. 10, No. 6, June, 2020, E-ISSN: 2222-6990 @ 2020 HRMARS

Table (5): French Instrumental Function

\begin{tabular}{|l|l|l|l|}
\hline Bil. & $\begin{array}{l}\text { Dialogue with French } \\
\text { words in the novel }\end{array}$ & $\begin{array}{l}\text { Dialogue's translations of } \\
\text { French words into English }\end{array}$ & \multicolumn{1}{|c|}{$\begin{array}{c}\text { Function } \\
\text { description }\end{array}$} \\
\hline 1. & $\begin{array}{l}\text { Tadpole: "Donne } \\
\text { bisou à Daddy!" }\end{array}$ & $\begin{array}{l}\text { Tadpole: "Give Daddy a } \\
\text { kiss!" }\end{array}$ & To submit a request \\
\hline 2. & $\begin{array}{l}\text { Mr. Frog: "But first we } \\
\text { have to } \\
\text { count...un, deux, } \\
\text { trois...souffle!" }\end{array}$ & $\begin{array}{l}\text { Mr. Frog: "But first we have } \\
\text { to count. One, two, three... } \\
\text { blow it!" }\end{array}$ & To emerge an instruction. \\
\hline
\end{tabular}

Table (5) shows two examples of dialogues highlighting the instrumental functions of French in which to submit a request and emerge an instruction.

\section{French Interaction Function}

The interaction function is defined as the role of a language to create and maintain social context between speakers and members of the community around them. For instance, through greeting words like saying good day, words of appreciation like granting compliments and words of sympathy such as saying condolences.

As a result of the corpus analysis conducted, a total of 8 data obtained regarding the French interaction function were recorded. These are two examples of French interaction function that have been inserted in the English dialogues:

Table (6): French Interaction Function

\begin{tabular}{|l|l|l|l|}
\hline Bil. & $\begin{array}{c}\text { Dialogue with French } \\
\text { words in the novel }\end{array}$ & $\begin{array}{c}\text { Dialogue's translations of French } \\
\text { words into English }\end{array}$ & \multicolumn{1}{c|}{$\begin{array}{c}\text { Function } \\
\text { description }\end{array}$} \\
\hline 1. & $\begin{array}{l}\text { Mr. Frog: "Bonsoir les } \\
\text { filles. I know you said I } \\
\text { could bring a friend, but } \\
\text { I'm pretty new in Paris- } \\
\text { I've just moved here to } \\
\text { look for a job- and I don't } \\
\text { know a lot of people." }\end{array}$ & $\begin{array}{l}\text { Mr. Frog: "Good evening ladies. I } \\
\text { know you said I could bring a friend, } \\
\text { but I'm pretty new in Paris- I've just } \\
\text { moved here to look for a job- and I } \\
\text { don't know a lot of people." }\end{array}$ & To address people. \\
\hline 2. & $\begin{array}{l}\text { Mr. Frog: "Oh don't be too } \\
\text { hard on yourself. They'll } \\
\text { rally around. And you're } \\
\text { stronger than you think. } \\
\text { Ca va aller, j'en suis sur". }\end{array}$ & $\begin{array}{l}\text { Mourself. They'll rally around. And } \\
\text { you're stronger than you think. It's } \\
\text { going to be alright, I'm sure". }\end{array}$ & To give persuasion. \\
\hline
\end{tabular}

According to the table (6), French is seen to have played an important role in interacting as it was used to address others and deliver persuasion. 
INTERNATIONAL JOURNAL OF ACADEMIC RESEARCH IN BUSINESS AND SOCIAL SCIENCES Vol. 10, No. 6, June, 2020, E-ISSN: 2222-6990 @ 2020 HRMARS

\section{French Personal Function}

In addition, according to Halliday (1973), the language personal function referred to as a communication tool that enables the speaker to express emotions and to respond to various emotions including happiness, sadness, affection, shame, excitement, frustration, fear and etch.

As a result of the content analysis, French also performed a personal function through the discovery of 5 data related to this category of communicative functions. However, this section will only discuss two examples of the foreign language's personal functions as set out in Table (7).

Table (7): French Personal Function

\begin{tabular}{|l|l|l|l|}
\hline Bil. & $\begin{array}{l}\text { Dialogue with French } \\
\text { words in the novel }\end{array}$ & $\begin{array}{l}\text { Dialogue's translations of } \\
\text { French words into English }\end{array}$ & \multicolumn{1}{|c|}{$\begin{array}{c}\text { Function } \\
\text { description }\end{array}$} \\
\hline 1. & $\begin{array}{l}\text { Catherine: "Oui, oui, } \\
\text { bien sur. I never worry } \\
\begin{array}{l}\text { when she's with you. I } \\
\text { know she's in good } \\
\text { hands". }\end{array}\end{array}$ & $\begin{array}{l}\text { Catherine: "Yes, yes, of } \\
\text { course. I never worry when } \\
\text { she's with you. I know she's } \\
\text { in good hands". }\end{array}$ & $\begin{array}{l}\text { To convey a sense of } \\
\text { calmness and confidence. }\end{array}$ \\
\hline 2. & $\begin{array}{l}\text { Mr. Frog: "Thank you, } \\
\text { Cath. Ca ma beaucoup } \\
\text { touché". }\end{array}$ & $\begin{array}{l}\text { Mr. Frog: "Thank you, Cath. } \\
\text { It's really touched me". }\end{array}$ & $\begin{array}{l}\text { To express the feeling of } \\
\text { being touched. }\end{array}$ \\
\hline
\end{tabular}

Based on table (7), French words that were included in the conversation of each character involved has reflected the personal function of using the foreign language in conveying a sense of calmness and confidence towards someone. Not only that, it also giving the character involved to express his feeling of being touched towards Catherine's attitude.

Generally, after analyzing the whole data, it is proven that the informative, instrumental, interaction and personal functions of French that were substituted in the English novel entitled Petite Anglaise has highlighted the use of code-switching in enhancing readers' knowledge regarding the French language which is the foreign language that was used in this casual reading medium. This can be seen with a comprehensive knowledge of French social culture which includes their well-known dishes, way of interacting, thinking and special phrases. Last but not least, even though each of the language communicative functions developed by Halliday (1973) have different features, the researchers find out that all of them carried the main purpose of using the language particularly French to create interaction within the characters involved and highlighting the bilingualism aspects in the creative writings which are the main catalyst of code-switching phenomenon.

\section{Conclusion}

The sociolinguistic phenomenon of code-switching that is known as the usage of two languages by speakers often appears in every level of communication including in creative writing 
such as the novels. Throughout the years, there are many arguments about the code-switching topic. In the acquisition topic of a foreign language like the French language, the practices of speakers shifting between this foreign language with their first or second language occur frequently including in Malaysia. They usually use code-switching English-French or vice versa. Some researchers argue that code-switching as less prestige and decreasing the fluency of the foreign language. However, based on the research that has been carried out, the use of code-switching in the novel which is a non-academic learning material has shown multiple communicative functions that open up an effective alternative in the foreign language's acquisition process. The research findings have proven that three types of code-switching English-French occur in the study material. In general, the most frequently used type of code-switching was intrasentential code-switching with $90.66 \%$ data. This type of exchange is elementary as it simply introduces foreign words into sentences from the same source text. Thus, this category allowed readers to understand the meaning of the language used more likely. Furthermore, intersentential code-switching recorded the second-highest frequency of $8.63 \%$ data. This type of code-switching requires an individual with high skills and comprehension to employ the languages involved. This is because the languages involved will be exchanged horizontally between each other to allow the messages convey can be understood by both parties. Whereas, tag code-switching, on the other hand, is the least used type of code-switching as they only account for $0.72 \%$ data. The overall content analysis results demonstrated that each category of code-switching used has certain features including uncomplicated, daily used words, requires high skill and knowledge to use languages in any form of communication.

Not only that, the result establishes that the French language used in the novel Petite Anglaise also had its communicative functions. According to Halliday (1973), there are seven language communicative functions but this research has restricted them to only four communicative functions namely informative functions, interaction functions, instrumental functions and personal functions as the author urged to review these functions in detail and the results may help for the future studies. As a result of the analysis, the informative function recorded the highest amount compared to the other with $75.53 \%$ data. Furthermore, the instrumental function came in second ranks with $10.07 \%$ data while the interaction function recorded $8.00 \%$ data and personal function with $3.59 \%$ data. Meanwhile, the remaining $2.89 \%$ data represented the other communicative functions namely heuristic functions, regulatory functions and imaginary functions that were not highlighted in this study.

Moreover, despite there are some parties that perceive this language phenomenon called code-switching as a culture that can damage the integrity of a language system, the study has concluded that it stimulates readers' interest and facilitates their understanding of foreign languages certainly French that were used in the Novel Petite Anglaise. This can be explained through the communicative functions of French which not only facilitated the speech of the characters involved but also helped to improve the readers' French acquisitions, especially to those who are fascinated by this language through the casual reading material. Additionally, in conducting this research, few shortcomings can be improved by future researchers who are interested to conduct a study regarding code-switching. Firstly, this research only focusing on one communication platform which is an English novel written by Catherine Sanderson. Plus, the researcher only emphasizes the use of a qualitative method which only analyses the research material and did not involve in getting the 
society's opinions regarding this issue. Future research was also suggested to look at other aspects of code-switching topics such as the factors and the field of studying this phenomenon. This is because this research only focuses on the communicative functions of code-switching based on Halliday (1973) theoretical framework and emphasis only in the sociolinguistic field.

Lastly, it is anticipated that this study will help to call attention mainly for individuals like the researchers and learners in the field of foreign language studies. This is due to this research importance in disclosing the role of code-switching as a communicative tool in enhancing the French language's acquisitions even though through the non-academic learning material like the English novel.

\section{References}

Abd. Wahad, K. B. (2018). Ciri dan Fungsi Komunikatif Bahasa Melayu Sabah dalam Media Sosial. Journal of Communication, Vol 34, Issue 4. Retrieved from http://ejournal.ukm.my/mjc/article/view/20525/8833.

Adi, W. T. (2018). Code-Switching in Critical Eleven Novel. Journal of Language, Literature and Teaching, Vol. 2, Issue 1. Retrieved from http://jurnal.untidar.ac.id/index.php/metathesis/article/view/514.

Appel, R., \& Musyken, P. (1987). Language Contact and Bilingualism. Great Britain: Athenaeum Press Ltd.

Cambridge Dictionary, Bahasa Inggeris- Bahasa Perancis (Electronic version). Retrieved from https://dictionary.cambridge.org.

Catherine Sanderson. (2008). Petite Anglaise (2 $2^{\text {nd }}$ ed.). New York, Penguin Group.

Collins Dictionary, Bahasa Inggeris-Bahasa Melayu (Electronic version). Retrieved from https://www.collinsdictionary.com.

Faridah, N. (2003). Campur Kod dan Alih Kod: Suatu Analisis Sosiolinguistik dalam Pembelajaran Bahasa Melayu. Master Thesis. Universiti Putra Malaysia, Serdang, Malaysia.

Halliday, M. A. K. (1973). Explorations in the functions of language. London: Edward Arnold.

Kamus Besar Bahasa Indonesia (Electronic version). Retrieved from https://www.typoonline.com/.

Kamus Dewan. (2005). Kuala Lumpur, Dewan Bahasa dan Pustaka.

Linguee Dictionary, Bahasa Inggeris-Bahasa Perancis (Electronic version). Retrieved from https://www.linguee.com.

Margana. (2009). Analisis Gramatika Alih Kod dari Bahasa Inggeris ke Bahasa Indonesia atau Sebaliknya. Scientific Journal of Language, Literature and Teaching. Vol 17, Issue 1. from https://journal.uny.ac.id/index.php/diksi/article/view/6576/5636.

Maros, M., Melissan, N. D., Zakaria, M. N. D. Abd. H. I. (2016). Code Switching as the Medium of Solidarity in "Ola Bola". Communication Journal, Vol 32, Issue 2. Retrieved from http://ejournal.ukm.my/mjc/article/view/16455/7606.

Moleong, L. J. (2007). Metodologi Penelitian Kualitatif. Bandung, Remaja Karya.

Oxford Dictionary, Bahasa Perancis- Bahasa Inggeris (Electronic version). Retrieved from https://en.oxforddictionaries.com > definition > french-english.

Patrick Hanks \& Laurence Urdang. (1979). Collins English Dictionary. Scotland, Harper Collins Publishers L.L.C.

Poplack, S. (1980). 'Sometimes I'll start a sentence in English y termino en español', Journal Linguistics, Vol 18, Issue 7/8. Retrieved from 
INTERNATIONAL JOURNAL OF ACADEMIC RESEARCH IN BUSINESS AND SOCIAL SCIENCES

Vol. 10, No. 6, June, 2020, E-ISSN: 2222-6990 @ 2020 HRMARS

http://www.sociolinguistics.uottawa.ca/shanapoplack/pubs/articles/Poplack1980Sometime s.pdf.

Stephen, C. A., Osup, C. A., \& Abu Bakar, S. S. (2017). Faktor Campur Kod dalam Kalangan Masyarakat Iban di Sarawak. Journal of Language, Literature and Education. Vol 8. Retrieved from https://ejournal.upsi.edu.my/index.php/PENDETA/article/view/1248/902.

Wardaugh, R. (2006). An introduction to sociolinguistics ( $5^{\text {th }}$ ed.). New York: Blackwell Publishing.

\section{Authors' Biodata}

\section{Corresponding Author}

Amirah Syazwani Roslan was born in Malacca, Malaysia in 1996. In 2019, she graduated with a Bachelor of Art (French Language) from Universiti Putra Malaysia (UPM). She is currently pursuing her studies in Master of Arts (Discourse Studies) under the Faculty of Modern Languages and Communication at Universiti Putra Malaysia (UPM).

\section{Co-author}

Assoc. Prof. Madya Dr. Omrah Hassan @ Hussin works at the Faculty of Modern Languages and Communication, Universiti Putra Malaysia (UPM) as the head of the Department of Foreign Languages. He obtained his Ph.D. in Linguistics from the Université Paris-Sorbonne, France. He has carried out on various topics related to the French language and comparative linguistics of the foreign language throughout the years. 